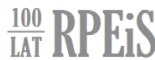

\section{SKUTECZNOŚĆ SKARGI NA PRZEWLEKLOŚĆ POSTĘPOWANIA PRZED NACZELNYM SĄDEM ADMINISTRACYJNYM (W ŚWIETLE ORZECZNICTWA)}

\section{UWAGI WPROWADZAJĄCE}

Elementem treści podmiotowego prawa do sądu jest uprawnienie do rozpoznania sprawy bez nieuzasadnionej zwłoki (art. 45 ust. 1 Konstytucji RP) lub w rozsądnym terminie (art. 6 Konwencji o ochronie praw człowieka i podstawowych wolności ${ }^{1}$ ). Stosownie do anglojęzycznej prawniczej maksymy ,justice delayed is justice denied”2 długotrwałość (przewlekłość) postępowania sądowego prowadzi do wypaczenia sensu dochodzenia przed sądami ochrony praw i wolności, których skuteczność zależy od ich sądowego zagwarantowania. Stanowi przy tym jedna z największych bolaczek polskiego wymiaru sprawiedliwości i najczęstszą przyczynę stwierdzania naruszeń przez Polskę praw gwarantowanych w EKPC ${ }^{3}$.

Naczelny Są Administracyjny jest w strukturze polskiego wymiaru sprawiedliwości organem o jednym z najdłuższych czasów oczekiwania na rozpoznanie sprawy i wydanie orzeczenia. Sprawa administracyjna, być może nawet sprawnie załatwiona przez organy administracji publicznej obu instancji i - na skutek wniesionej skargi - przez wojewódzki sąd administracyjny, gdy po wniesieniu skargi kasacyjnej trafi do NSA, oczekuje na rozstrzygnięcie, jak pokażą statystyki zaprezentowane w niniejszym artykule, przez okres nawet

* Michał Szwast, Uniwersytet Warszawski,

m.szwast@wpia.uw.edu.pl, https://orcid.org/0000-0001-9431-5908

1 Konwencja o ochronie praw człowieka i podstawowych wolności sporządzona w Rzymie dnia 4 listopada 1950 r., zmieniona następnie Protokołami nr 3, 5 i 8 oraz uzupełniona Protokołem nr 2, Dz. U. 1993, Nr 61, poz. 284 ze zm. (dalej jako: EKPC).

2 „Spóźniona sprawiedliwość jest odmową sprawiedliwości”.

${ }^{3}$ Hofmański, Wróbel (2010): 249 oraz 364-365, zob. również Brzozowski, Krzywoń, Wiącek (2018): 165. 
2-3 lat ${ }^{4}$. Rzutuje to niekorzystnie na ochronę jednostki przed działaniami (lub zaniechaniami) organów administracji i rodzi wątpliwości co do efektywności sprawowanej przez sądy administracyjne kontroli działalności administracji publicznej (art. 184 Konstytucji RP).

Biorąc pod uwagę tę skrótowo zarysowaną problematykę, zasadne jest przeanalizowanie funkcjonowania instytucji skargi na naruszenie prawa strony do rozpoznania sprawy w postępowaniu sądowym bez nieuzasadnionej zwłoki (dalej jako: skarga na przewlekłość postępowania5) w zakresie postępowania przed NSA. W założeniu ustawodawcy miał być to bowiem podstawowy instrument zmierzający zarówno do stwierdzenia przewlekłości postępowania sądowego oraz nakazania jej usunięcia, jak i zasądzenia zadośćuczynienia pieniężnego na rzecz pokrzywdzonej przewlekłością strony postępowania. Celem artykułu jest tym samym przeanalizowanie funkcjonowania w praktyce skargi na przewlekłość postępowania przed NSA, ocena jej efektywności z punktu widzenia realizacji prawa do sądu i prawa do skutecznego środka zaskarżenia, jak również zidentyfikowanie ewentualnych problemów oraz mankamentów w zakresie jej skuteczności. W bogatym piśmiennictwie dotyczącym skargi na przewlekłość postępowania sądowego dotychczas nie podejmowano się opracowania tego zagadnienia ${ }^{6}$. Analiza skoncentruje się zarówno na przeglądzie tendencji orzeczniczych, ocenie kierunku rozstrzygania skarg, jak również dostępnych statystyk obrazujacych czas trwania postępowania przed NSA oraz odsetka uwzględnianych skarg na przewlekłość postępowania w pięciu ostatnich latach. Jej celem jest sformułowanie wniosków zarówno pod adresem NSA, jak i ustawodawcy co do pożądanych kierunków zmian w obszarze mechanizmu skargi na przewlekłość postępowania sądowego, biorąc pod uwagę wymagania konstytucyjne i prawnomiędzynarodowe.

\footnotetext{
${ }^{4}$ Czas trwania postępowań przed sądami powszechnymi należy także uznać za niesatysfakcjonujący, niemniej statystyki sądowe pokazuja, że na rozstrzygnięcie sprawy przed sądem II instancji czeka się krócej niż przed NSA. Wedle najbardziej aktualnych danych za 2018 r. w sądach apelacyjnych na rozstrzygnięcie w przedmiocie apelacji w sprawach karnych czekało się średnio 108,5 dnia, a w sprawach cywilnych - 301,1 dnia; w sądach okręgowych na rozstrzygnięcie w przedmiocie apelacji w sprawach karnych i wykroczeniowych czekało się średnio 84,9 dnia, a w sprawach cywilnych - 180,4 dnia. Dane za tabela „Wskaźniki dotyczące spraw w Polsce według działów prawa i instancyjności w roku 2017 i w roku 2018” zawartą w pliku „Ewidencja spraw według działów prawa i instancyjności w 2018 roku”, dostępnym w „Informatorze Statystycznym Wymiaru Sprawiedliwości”, <https://isws.ms.gov.pl/pl/baza-statystyczna/opracowania-jednoroczne/rok-2018/ download,3787,0.html>.

${ }^{5}$ Skarga funkcjonuje na podstawie ustawy z 17 czerwca 2004 r. o skardze na naruszenie prawa strony do rozpoznania sprawy w postępowaniu przygotowawczym prowadzonym lub nadzorowanym przez prokuratora i postępowaniu sądowym bez nieuzasadnionej zwłoki, t.jedn.: Dz. U. 2018, poz. 75 ze zm. (dalej jako: u.s.p.).

${ }^{6} \mathrm{~W}$ literaturze podejmowano rozważania teoretyczne nad poszczególnym aspektami funkcjonowania ustawy o skardze na przewlekłość: Krakowiak (2007); Kłak (2008); Stefanicki (2016); Kładoczny et al. (2010), również w kontekście orzecznictwa sąów administracyjnych: zob. w szczególności: Celińska-Grzegorczyk (2018); Ryms (2010). Natomiast opracowania te nie ujmowały problematyki z perspektywy przyjętej w niniejszym artykule, tj. efektywności funkcjonowania instytucji skargi na przewlekłość postępowania przed NSA w praktyce i w kontekście zgodności z orzecznictwem Europejskiego Trybunału Praw Człowieka.
} 


\section{ZARYS PROBLEMATYKI DOTYCZĄCEJ SKARGI NA PRZEWLEKLOŚĆ POSTĘPOWANIA}

Uchwalenie ustawy o skardze na przewlekłość postępowania było konsekwencją wykonania przez Rzeczpospolitą Polska postanowień wyroku Wielkiej Izby Europejskiego Trybunału Praw Człowieka z 26 października 2000 r. w sprawie Kudta przeciwko Polsce ${ }^{7}$. Trybunał, uznajac naruszenie przez Polskę m.in. art. 6 (prawo do rzetelnego procesu sądowego) oraz art. 13 EKPC (prawo do skutecznego środka zaskarżenia), wskazał w nim, że przewlekłość postępowań przed polskimi sądami ma charakter systemowy, a prawo polskie nie przewiduje skutecznego mechanizmu przeciwdziałania temu zjawisku ani rekompensowania podmiotom prawa do sądu szkód z nim związanych.

Zawężając na potrzeby niniejszego artykułu wielowątkową problematykę skargi na przewlekłość wyłącznie do postępowania sądowoadministracyjnego, należy wskazać, że uprawnionym do jej wniesienia jest skarżący oraz uczestnik postępowania na prawach strony (art. 3 pkt 6 u.s.p.). Jeżeli skarga dotyczy przewlekłości postępowania przed wojewódzkim sądem administracyjnym lub NSA - właściwy do jej rozpoznania jest NSA (art. 4 ust. 3). Skargę o stwierdzenie, że w postępowaniu, którego skarga dotyczy, nastapiła przewlekłość postępowania, wnosi się w toku postępowania w sprawie do sądu, przed którym toczy się postępowanie (art. 5 ust. 1 i 2). Skarga powinna zawierać: 1) żądanie stwierdzenia przewlekłości postępowania w sprawie, której skarga dotyczy; 2) przytoczenie okoliczności uzasadniających żądanie (art. 6 ust. 2). Brak spełnienia tych warunków skutkuje odrzuceniem skargi przez sąd bez wzywania do uzupełnienia braków (art. 9 ust. 1). Skargę niezasadną sąd oddala (art. 12 ust. 1). Uwzględniając skargę, sąd stwierdza, że w postępowaniu, którego skarga dotyczy, nastapiła przewlekłość postępowania (art. 12 ust. 1). Na żądanie skarżącego lub z urzędu sąd zaleca podjęcie przez sąd rozpoznający sprawę co do istoty odpowiednich czynności w wyznaczonym terminie, chyba że wydanie zaleceń jest oczywiście zbędne. Zalecenia nie mogą wkraczać w zakres oceny faktycznej i prawnej sprawy (art. 12. ust. 3). Uwzględniając skargę, sąd na żądanie skarżącego przyznaje od Skarbu Państwa sumę pieniężną w wysokości od 2000 do 20000 zł. Wysokość sumy pieniężnej w powyższych granicach wynosi nie mniej niż 500 zł za każdy rok dotychczasowego trwania postępowania, niezależnie od tego, ilu etapów postępowania dotyczy stwierdzona przewlekłość postępowania. Sąd może przyznać sumę pieniężną wyższą niż 500 zł za każdy rok dotychczasowego trwania postępowania, jeżeli sprawa ma szczególne znaczenie dla skarżącego, który swoją postawą nie przyczynił się w sposób zawiniony do wydłużenia czasu trwania postępowania. Na poczet tej sumy zalicza się kwoty przyznane już skarżącemu tytułem sumy pieniężnej w tej samej sprawie (art. 12 ust. 4). Skarżący może wystapić z nową skarga w tej samej sprawie po upływie 12 miesięcy (art. 14 ust. 1). Strona, której skargę uwzględniono, może w odrębnym postępowaniu dochodzić naprawienia

\footnotetext{
${ }^{7}$ Skarga nr 30210/96.
} 
szkody wynikłej ze stwierdzonej przewlekłości od Skarbu Państwa albo solidarnie od Skarbu Państwa i komornika. Postanowienie uwzględniające skargę wiąże sąd w postępowaniu cywilnym o odszkodowanie lub zadośćuczynienie co do stwierdzenia przewlekłości postępowania (art. 15 ust. 1 i 2).

W 2015 r. ETPC wydał wyrok w sprawie Rutkowski i Inni przeciwko Pol$s c e^{8}$, w którym krytycznie odniósł się do niektórych aspektów funkcjonowania mechanizmu skargi na przewlekłość postępowania, ponownie stwierdzając naruszenie przez Polskę art. 6 i art. 13 EKPC. Wyrok miał jednocześnie charakter tzw. orzeczenia pilotażowego, objęto nim także 591 innych analogicznych skarg, wniesionych w od 4 marca 2008 r. do 23 maja 2015 r. ${ }^{9}$ Trybunał zidentyfikował strukturalny problem $\mathrm{w}$ zakresie funkcjonowania skargi na przewlekłość, polegający, po pierwsze, na ograniczaniu przez niektóre polskie sądy badania przewlekłości do wyłącznie tego etapu postępowania (instancji), w której wnoszona jest skarga na przewlekłość, a po drugie, na zaniżaniu wysokości zasądzanych przez sądy zadośćuczynień pieniężnych z tytułu przewlekłości ${ }^{10}$.

W konsekwencji wydania tego wyroku ustawodawca uchwalił ustawę z 30 listopada 2016 r. o zmianie ustawy - Prawo o ustroju sądów powszechnych oraz niektórych innych ustaw ${ }^{11}$, która znowelizowała przepisy ustawy o skardze na przewlekłość. Zmiany dotyczyły m.in. zobowiązania sądów do stosowania przepisów ustawy zgodnie ze standardami wynikającymi z EKPC ${ }^{12}$ (art. 1 ust. 3), uwzględniania przy ocenie przewlekłości postępowania łącznego dotychczasowego czasu postępowania od jego wszczęcia do chwili rozpoznania skargi, niezależnie od tego, na jakim etapie skarga została wniesiona (art. 2 ust. 2), oraz wprowadzenia bardziej precyzyjnych reguł wyliczania zadośćuczynienia pieniężnego (art. 12 ust. 4).

Z powyższego wynika, że skarga na przewlekłość postępowania stanowi ustawowy mechanizm zapewnienia prawa jednostki do rozpoznania sprawy w rozsądnym terminie, którego wprowadzenie i kształt sa skutkiem rozstrzygania skarg indywidualnych przeciwko Polsce przez ETPC. Zatem aby spełnić wymagania standardów wynikających z EKPC, powinien być to mechanizm efektywny, którego wykorzystanie przez stronę postępowania doprowadzi zarówno do stwierdzenia przewlekłości, jak i do usunięcia jej skutków oraz ewentualnego zasądzenia zadośćuczynienia pieniężnego. Aby ocenić efektywność skargi na przewlekłość wnoszonej w postępowaniu przed NSA, trzeba najpierw odwołać się do oficjalnych statystyk sądowych dotyczacych czasu trwania postępowań przed tym sądem. To bowiem pozwoli na ocenę, czy jest to sąd dotknięty strukturalnym problemem długotrwałości postępowań sądowych.

\footnotetext{
${ }^{8}$ Wyrok z 7 lipca 2015 r., skargi nr 72287/10, 13927/11, 46187/11.

${ }^{9}$ Zob. Pietryka (2015): 1-2.

${ }^{10}$ Pietryka (2015): $3 \mathrm{n}$.

${ }^{11}$ Dz. U. 2016, poz. 2103.

${ }^{12}$ Czyli zgodnie ze standardami wynikajacymi z orzecznictwa ETPC na gruncie spraw dotyczących naruszeń art. 6 i art. 13 EKPC.
} 


\section{CZAS OCZEKIWANIA NA ROZPOZNANIE SKARGI KASACYJNEJ PRZEZ NSA}

Precyzyjne ustalenie średniego czasu trwania postępowania przed NSA, liczonego od wpływu do tego sądu skargi kasacyjnej od wyroku wojewódzkiego sądu administracyjnego aż do wydania w sprawie orzeczenia, nie jest możliwe. W statystykach udostępnianych przez NSA brak bowiem jednoznacznych danych wskazujących na średni czas trwania postępowania. By jednak w możliwie najpełniejszy sposób zobrazować tę problematykę, można poddać analizie inne dostępne dane. Przede wszystkim warto odwołać się do statystyk w zakresie terminowości rozpatrywania skarg kasacyjnych z podziałem na poszczególne okresy liczone od daty wpływu sprawy do jej rozstrzygnięcia. Dane za lata 2015-2020 obrazuje poniższa tabela.

Tabela 1

Terminowość rozstrzygania skarg kasacyjnych

(okres od daty wpływu sprawy w danym lub poprzednim okresie sprawozdawczym do daty jej zakończenia)

\begin{tabular}{|c|c|c|c|c|c|c|c|}
\hline $\begin{array}{c}\text { Rok } \\
\text { sprawo- } \\
\text { zdaw- } \\
\text { czy }\end{array}$ & $\begin{array}{c}\text { Sprawy } \\
\text { rozstrzyg- } \\
\text { nięte } \\
\text { do 2 mie- } \\
\text { sięcy }\end{array}$ & $\begin{array}{c}\text { Sprawy } \\
\text { rozstrzyg- } \\
\text { nięte } \\
\text { powyżej 2 } \\
\text { miesięcy } \\
\text { do 3 mie- } \\
\text { sięcy }\end{array}$ & $\begin{array}{c}\text { Sprawy } \\
\text { rozstrzyg- } \\
\text { nięte } \\
\text { powyżej 3 } \\
\text { miesięcy } \\
\text { do 4 mie- } \\
\text { sięcy }\end{array}$ & $\begin{array}{c}\text { Sprawy } \\
\text { rozstrzyg- } \\
\text { nięte } \\
\text { powyżej 4 } \\
\text { miesięcy } \\
\text { do 6 mie- } \\
\text { sięcy }\end{array}$ & $\begin{array}{c}\text { Sprawy } \\
\text { roz- } \\
\text { strzyg- } \\
\text { nięte } \\
\text { powyżej 6 } \\
\text { miesięcy } \\
\text { do 12 } \\
\text { miesięcy }\end{array}$ & $\begin{array}{c}\text { Sprawy } \\
\text { rozstrzyg- } \\
\text { nięte po- } \\
\text { wyżej 12 } \\
\text { miesięcy } \\
\text { do 24 } \\
\text { miesięcy }\end{array}$ & $\begin{array}{c}\text { Sprawy } \\
\text { rozstrzyg- } \\
\text { nięte po- } \\
\text { wyżej 24 } \\
\text { miesięcy }\end{array}$ \\
\hline $\mathbf{2 0 2 0}$ & 1059 & 787 & 924 & 1302 & 2884 & 4375 & 4445 \\
\hline $\mathbf{2 0 1 9}$ & 685 & 614 & 590 & 781 & 1204 & 8312 & 4271 \\
\hline $\mathbf{2 0 1 8}$ & 1252 & 783 & 577 & 1459 & 2866 & 7238 & 4855 \\
\hline $\mathbf{2 0 1 7}$ & 978 & 601 & 489 & 1084 & 2236 & 10211 & 3668 \\
\hline $\mathbf{2 0 1 6}$ & 699 & 346 & 321 & 671 & 1626 & 10045 & 3227 \\
\hline $\mathbf{2 0 1 5}$ & 973 & 550 & 488 & 580 & 1369 & 8788 & 2226 \\
\hline
\end{tabular}

Źródło: opracowanie własne na podstawie danych dostępnych na stronie internetowej NSA: „Zażalenia, wnioski, skargi szczególne, inne (...)”, dział 11 lub 13 „Terminowość załatwiania spraw” dla każdego roku sprawozdawczego), <http://www.nsa.gov.pl/statystyki-nsa.php>.

Analiza powyższych danych prowadzi do wniosku, że generalnie utrzymuje się wysoki odsetek spraw rozpoznanych po upływie co najmniej 12 miesięcy od dnia wpływu w stosunku do liczby ogółem rozpoznanych spraw. W 2015 r. było to 73\% spraw, 2016-78\%, $2017-72 \%, 2018-63,5 \%$, 2019 - 76\%, 2020 - 56\%. Ponadto stale rośnie liczba spraw rozpoznanych po upływie dwóch lat od daty wpływu skargi kasacyjnej: w 2015 r. stanowiły 
one $15 \%$ ogółu rozpoznanych spraw, $2016-19 \%, 2017-19 \%, 2018-25,5 \%$, $2019-26 \%, 2020-28 \%$.

Badając problematykę długotrwałości postępowania przed NSA, należy również odwołać się do statystyk w zakresie liczby spraw niezałatwionych na koniec każdego z sześciu ostatnich lat kalendarzowych (2015-2020) z podziałem na okresy, w których dana liczba spraw oczekuje nadal na załatwienie. Dane przedstawia tabela 2.

Tabela 2

Sprawy niezałatwione

(od daty pierwszego wpływu skargi kasacyjnej do NSA)

\begin{tabular}{|c|c|c|c|c|c|}
\hline $\begin{array}{c}\text { Rok } \\
\text { sprawo- } \\
\text { zdaw- } \\
\text { czy }\end{array}$ & $\begin{array}{c}\text { Sprawy } \\
\text { oczekujące } \\
\text { powyżej } \\
\text { 3 do 6 mie- } \\
\text { sięcy }\end{array}$ & $\begin{array}{c}\text { Sprawy } \\
\text { oczekujące } \\
\text { powyżej } \\
\mathbf{6} \text { do } \mathbf{1 2} \text { mie- } \\
\text { sięcy }\end{array}$ & $\begin{array}{c}\text { Sprawy } \\
\text { oczekujące } \\
\text { powyżej 12 } \\
\text { miesięcy do } \\
\mathbf{2} \text { lat }\end{array}$ & $\begin{array}{c}\text { Sprawy } \\
\text { oczekujące } \\
\text { powyżej 2 } \\
\text { do 3 lat }\end{array}$ & $\begin{array}{c}\text { Sprawy } \\
\text { oczekujące } \\
\text { powyżej } \\
\text { 3 lat }\end{array}$ \\
\hline $\mathbf{2 0 2 0}$ & 2900 & 3961 & 9820 & 6556 & 287 \\
\hline $\mathbf{2 0 1 9}$ & 4158 & 6867 & 11235 & 1916 & 298 \\
\hline $\mathbf{2 0 1 8}$ & 4213 & 7282 & 11071 & 1195 & 272 \\
\hline $\mathbf{2 0 1 7}$ & 4183 & 6829 & 11022 & 600 & 117 \\
\hline $\mathbf{2 0 1 6}$ & 4235 & 8968 & 10711 & 529 & 35 \\
\hline $\mathbf{2 0 1 5}$ & 4396 & 8176 & 8944 & 777 & 10 \\
\hline
\end{tabular}

Źródło: opracowanie własne na podstawie danych dostępnych na stronie internetowej NSA: „Zażalenia, wnioski, skargi szczególne, inne (...)”, dział 8 „Sprawy niezałatwione” dla każdego roku sprawozdawczego, <http://www.nsa.gov.pl/statystyki-nsa.php>.

Należy podkreślić, że wyżej przedstawione dane nie prezentują liczby spraw rozpatrzonych w podanych tam przedziałach czasu, a liczbę spraw nadal pozostajacych do rozpatrzenia na koniec danego roku kalendarzowego. Oznacza to, że ujęte tam sprawy rozstrzygane są de facto w jeszcze dłuższych terminach. Z zestawienia tych danych można wysnuć wniosek, że - po pierwsze - z każdym kolejnym rokiem zmniejsza się udział spraw oczekujących na rozpatrzenie powyżej 6 do 12 miesięcy na rzecz terminów dłuższych, tj. powyżej 12 miesięcy do 2 lat oraz powyżej 2 do 3 lat. Istotny wzrost liczby spraw o ponaddwuletniej zaległości widać pomiędzy rokiem 2017 a 2018 (595 spraw), 2018 a 2019 (721 spraw), a dramatyczny pomiędzy rokiem 2019 a 2020 (4640 spraw). Po drugie, co szczególnie niepokojące, wzrasta odsetek spraw nierozpoznanych przez NSA przez ponad 3 lata od daty wpływu skargi kasacyjnej. Na koniec 2015 r. takich spraw było jedynie 10, podczas gdy na koniec 2020 - już 287. Po trzecie, warto wskazać, że w ostatnim roku z analizowanych lat sprawozdawczych aż 71\% spraw oczekujących na rozpoznanie wpłynęło dawniej niż rok wstecz (16 663 z 23 524) i aż 29\% dawniej niż dwa lata wstecz (6843 z 23524$)$. 
Analiza powyższych danych statystycznych pozwala na postawienie tezy, że w postępowaniu przed NSA czas oczekiwania na rozstrzygnięcie sprawy od momentu jej wpływu wynosi w większości przypadków średnio ok. 18-24 miesięcy. Występuje tym samym przewlekłość postępowania o charakterze powszechnym i strukturalnym. Przyczyny tej przewlekłości zostaną omówione w dalszych częściach artykułu.

\section{STATYSTYKA SPRAW ZE SKARG NA PRZEWLEKŁOŚĆ POSTĘPOWANIA PRZED NSA}

W celu zobrazowania funkcjonowania w praktyce instytucji skargi na przewlekłość postępowania przed NSA warto zaprezentować oficjalne statystyki dotyczące liczby rozpatrzonych skarg, w tym odsetka skarg uwzględnionych przez NSA. Ograniczymy się przy tym, podobnie jak przy prezentowaniu czasu trwania postępowania, do lat 2015-2020.

W latach 2015-2020 NSA rozpoznał łącznie 212 skarg na przewlekłość postępowania przed tym sądem. Spośród powyższych spraw jedynie trzy zakończyły się wydaniem postanowienia o uwzględnieniu skargi. Dwa takie postanowienia wydano w 2015 i jedno w 2016 r. Stopień uwzględnienia skarg na przewlekłość postępowania przed NSA w analizowanym okresie wyniósł zatem zaledwie $1,41 \%$. Uwage zwraca fakt, że w ostatnich czterech latach nie uwzględniono ani jednej skargi. W każdej ze spraw zakończonych pozytywnie dla skarżących zasądzono zadośćuczynienie pieniężne. Łącznie było to $15000 \mathrm{zl}^{13}$.

Oficjalne statystyki sądowe pokazuja, że po pierwsze, skarga na przewlekłość postępowania przed NSA jest stosunkowo rzadko wykorzystywanym środkiem ochrony praw przez strony postępowania, mimo stałej długotrwałości tego postępowania w latach 2015-2020. Trudno wskazać na jedna, niewątpliwą przyczynę tego zjawiska. Wydaje się, że po części wynika to z niskiej świadomości prawnej stron postępowania co do istnienia i zasad wnoszenia skargi na przewlekłość i korzyści (w tym materialnych) związanych z jej uwzględnieniem. Możliwe jest także przekonanie u stron postępowania, że wniesienie skargi na przewlekłość jest pozbawione celu, skoro praktyka pokazuje, że skargi te nie sa prawie wcale uwzględniane oraz że skoro właściwym do rozstrzygnięcia w ich przedmiocie jest sam NSA, to szansa na wydanie orzeczenia uwzględniającego skargę jest niewielka. Być może część stron obawia się także skutku, jaki wniesienie skargi na przewlekłość w toku postępowania przed NSA będzie miało na kierunek rozstrzygnięcia sprawy głównej przez ten sąd i powstania stanu uprzedzenia sądu względem strony. W tym sensie przepisy powierzające rozpoznanie skargi na przewlekłość postępowania przed NSA temu sądowi mogą wywoływać sui generis „efekt mrożący”.

${ }^{13}$ Informacje dostępne na stronie internetowej NSA: „Zażalenia, wnioski, skargi szczególne, inne”, <http://www.nsa.gov.pl/statystyki-nsa.php>. 
Przyczyną rzadkiego wnoszenia tych skarg może być nadto obawa stron postępowania, że zainicjowane postępowanie wpadkowe jeszcze bardziej wydłuży czas rozpoznania sprawy głównej.

Statystyka sądowa pokazuje wyraźnie, że NSA prawie wcale nie uwzględnia skarg na przewlekłość postępowania przed NSA. Należy zatem przeanalizować, jakie argumenty NSA podaje w uzasadnieniach swoich postanowień.

\section{ANALIZA ORZECZNICTWA NSA W SPRAWACH ZE SKARGI NA PRZEWLEKLOŚĆ POSTĘPOWANIA PRZED NSA}

Analiza losowo wybranych kilkunastu postanowień NSA oddalajacych skargi na przewlekłość postępowania przed tym sądem pozwala na postawienie tezy o utrwalonej linii argumentacji w takich sprawach ${ }^{14}$. NSA odmawiając stwierdzenia przewlekłości postępowania w sprawach, w których postępowanie trwa nawet od ponad dwóch lat od daty wpływu, powołuje się na dużą liczbę rozpoznawanych przezeń spraw i konieczność oczekiwania sprawy, w której wniesiono skargę o stwierdzenie przewlekłości, na rozpoznanie zgodnie z kolejnością wpływu.

Przede wszystkim w badanych sprawach NSA twierdzi na wstępie, że „o nieuzasadnionej zwłoce można mówić wówczas, jeżeli postępowanie w sprawie trwa dłużej, niż to konieczne, uwzględniając ocenę terminowości i prawidłowości czynności sądowych, ale także zachowań stron, a w szczególności strony, która zarzuciła przewlekłość postępowania. Ocena ta nie może być oderwana od obowiąku sądu rozpoznania wszystkich spraw wniesionych do sądu bez nieuzasadnionej zwłoki, przy zachowaniu zasady rozpoznawania spraw według kolejności ich wpływu oraz uwzględnieniu przepisów nakazujących rozpoznanie niektórych rodzajów spraw w ustawowo określonych terminach" ${ }^{15}$.

Następnie NSA zwykle przywołuje treść przepisów dotyczacych zasad wyznaczania spraw na wokandę. Wskazuje, że „stosownie do przepisu $§ 49$ ust. 1 uchwały Zgromadzenia Ogólnego Sędziów Naczelnego Sądu Administracyjnego z dnia 8 listopada $2010 \mathrm{r}$. w sprawie regulaminu wewnętrznego urzędowania Naczelnego Sądu Administracyjnego (M.P. Nr 86, poz. $1007^{16}$ ) sprawy wpływające ze środkami odwoławczymi od orzeczeń wojewódzkich sadów administracyjnych należy rozpoznawać według kolejności ich wpływu do Sądu, chyba że przepis szczególny stanowi inaczej. Powyższe oznacza, że sprawa wniesiona później nie może być rozpoznana (nie można wyznaczyć terminu

${ }^{14}$ Wybrano postanowienia wydawane przez wszystkie Izby NSA: Ogólnoadministracyjna, Finansową i Gospodarcza, opublikowane w Centralnej Bazie Orzeczeń Sądów Administracyjnych.

${ }_{15}$ Tak np. postanowienia NSA z: 18 marca 2016 r., II FPP 5/16; 5 lutego 2016 r., I GPP 1/16; 31 stycznia 2019 r., II GPP 1/19; 10 sierpnia 2016 r., I OPP 84/16; 25 marca 2015 r., I OPP 23/15; 24 lipca 2019 r., I OPP 19/19; 8 listopada 2019 r., I OPP 51/19; 8 listopada 2019 r., I OPP 81/19.

${ }^{16}$ Uchwała ta utraciła moc z dniem 7 lipca 2020 r. na skutek wejścia w życie rozporządzenia Prezydenta RP z 4 lipca 2020 r. - Regulamin Naczelnego Sądu Administracyjnego (Dz. U. 2020, poz. 1202). 
rozprawy) przed rozpoznaniem spraw, które zostały wniesione do sądu wcześniej”" ${ }^{17}$. NSA podkreśla przy tym, że „liczba spraw wniesionych do Sądu jest przyczyną oczekiwania na wyznaczenie terminu rozprawy"18. Czasem NSA podaje, ile w danym momencie wynosi czas oczekiwania na wyznaczenie terminu rozprawy ${ }^{19}$, tym samym argumentując, że sprawa objęta skargą na przewlekłość nie oczekiwała na rozpoznanie dłużej niż inne sprawy w danej Izbie.

W dalszej kolejności NSA argumentuje, że „ustawa nie określa wprost, jaki okres oczekiwania na rozpoznanie sprawy należy uznać za nieuzasadnioną zwłokę. Pewna wskazówka wynika jednak z art. 14 ustawy, który stanowi, że skarżący może wystapić z nową skargą w tej samej sprawie po upływnie 12 miesięcy [...], ustawodawca uznał za przewlekłe takie postępowanie, które trwa dłużej niż 12 miesięcy. Przy czym, jeżeli postępowanie trwa dłużej niż 12 miesięcy, nie oznacza to samo przez się, że nastapiła przewlekłość postępowania w rozumieniu tej ustawy" 20 .

W większości przeanalizowanych spraw skargi na przewlekłość zostały oddalone wyraźnie po upływie 12 miesięcy od daty zarejestrowania w NSA skargi kasacyjnej w sprawie, w której strona domagała się stwierdzenia przewlekłości ${ }^{21}$. Mimo tak długo trwającego postępowania NSA, oddalając skargi, podnosił, że nie doszło do nieuzasadnionej zwłoki w rozpoznaniu sprawy, albowiem po prawidłowym i terminowym wykonaniu wstępnych czynności sądowych, sprawa oczekiwała na wyznaczenie terminu rozprawy zgodnie z kolejnościa wpływu, natomiast znaczna liczba spraw wpływających ze środkami odwoławczymi do NSA stanowi przyczynę oczekiwania na wyznaczenie terminu rozprawy i co się z tym wiąże - przyczynę oczekiwania na rozpoznanie sprawy ${ }^{22}$. NSA ubocznie podnosił także, że sprawy, w których strony wnosiły skargi na przewlekłość postępowania przed NSA nie należą do grupy spraw, których przepisy prawa nakazują rozpatrywanie w określonych terminach, a nadto że

17 Tak np. postanowienia NSA z: 7 grudnia 2015 r., I OPP 144/15; 4 lipca 2019 r., I OPP 19/19; 8 listopada 2019 r., I OPP 81/19; 31 stycznia 2019 r., II GPP 1/19; 5 lutego 2016 r., I GPP 1/16; 18 marca 2016 r., II FPP 5/16.

18 Zob. orzeczenia powyżej.

19 Przykładowo w postanowieniu z 31 stycznia 2019 r., II GPP 1/19 NSA wskazywał, że „termin rozpatrzenia sprawy ze skargi kasacyjnej złożonej do Naczelnego Sądu Administracyjnego Izby Gospodarczej, który wyznaczony jest liczbą złożonych skarg kasacyjnych oscyluje od dwóch lat do dwóch i pół roku”. W postanowieniu z 5 lutego 2016 r., I GPP 1/16 NSA wskazywał natomiast, że „w chwili obecnej średni okres oczekiwania na rozpoznanie sprawy w I Wydziale Izby Gospodarczej Naczelnego Sądu Administracyjnego wynosi około 18 miesięcy”. W postanowieniu z 18 marca 2016 r., II FPP 5/16 NSA podnosił z kolei, że „w chwili obecnej średni okres oczekiwania na rozpoznanie sprawy w Wydziale II Izby Finansowej Naczelnego Sądu Administracyjnego wynosi około 30 miesięcy".

20 Tak np. postanowienia NSA z: 7 grudnia 2015 r., I OPP 144/15; 4 lipca 2019 r., I OPP 19/19; 8 listopada 2019 r., I OPP 51/19; 8 listopada 2019 r., I OPP 81/19; 31 stycznia 2019 r., II GPP 1/19; 18 marca 2016 r., II FPP 5/16; 25 marca 2015 r., I OPP 23/15.

${ }^{21}$ NSA nie uznawał za przewlekłe postępowań, które w momencie rozpoznania skargi na przewlekłość trwały przed NSA np. 26 miesięcy (I OPP 19/19), 25 miesięcy (II GPP 1/19), 18 miesięcy (I OPP 23/15).

22 Tak np. postanowienia NSA z: 7 grudnia 2015 r., I OPP 144/15; 4 lipca 2019 r., I OPP 19/19; 8 listopada 2019 r., I OPP 51/19; 8 listopada 2019 r., I OPP 81/19, 18 marca 2016 r., II FPP 5/16, z 10 sierpnia 2016 r., I OPP 84/16; 25 marca 2015 r., I OPP 23/15. 
strony nie występowały do Prezesa Izby NSA, w której toczy się sprawa, o jej rozpoznanie poza kolejnością wpływu ${ }^{23}$.

W latach 2015-2020 NSA uwzględnił skargę na przewlekłość postępowania przed tym sądem jedynie w trzech sprawach ${ }^{24}$. W orzeczeniach tych NSA brał pod uwagę znaczenie przedmiotu sprawy dla skarżącej w kontekście łącznego czasu trwania całego postępowania administracyjnego i sądowoadministracyjnego (sprawa dotyczyła ustanowienia prawa użytkowania wieczystego nieruchomości warszawskiej) ${ }^{25}$, trwające 3 lata postępowanie sądowe w obu instancjach w sprawie dotyczącej przyznania zasiłku stałego z pomocy społecznejej ${ }^{26}$ okoliczność, że postępowanie sądowe zainicjowane przez skarżącego w przedmiocie stwierdzenia niedopuszczalności odwołania trwało ponad 4 lata (sprawa była rozpatrywana przez NSA dwukrotnie, na skutek uchylenia wyroku sądu I instancji - pierwsze postępowanie przed NSA trwało ponad 17 miesięcy, a kolejne - w momencie wniesienia skargi na przewlekłość 20 miesięcy) $)^{27}$.

Wszystkie orzeczenia uwzględniające skargę na przewlekłość zapadły w Izbie Ogólnoadministracyjnej NSA, a zasądzone w ramach zadośćuczynienia sumy pieniężne pozostawały raczej przy dolnej granicy wynikającej z ustawy o skardze na przewlekłość.

\section{DOSTRZEŻONE PROBLEMY I POSTULATY MAJĄCE NA CELU ICH WYELIMINOWANIE}

Dotychczasowe ustalenia prowadzą do wniosku, że skarga na przewlekłość postępowania przed NSA jest mechanizmem, z którego strony korzystaja mimo trwających kilkanaście miesięcy postępowań sądowych - bardzo rzadko. Ponadto ustalono, że odsetek skarg uwzględnionych jest niezmiernie niski i w latach 2015-2020 wynosił mniej niż 1,5\%. Pozwala to na postawienie tezy, że instytucja ta ma w praktyce charakter nieefektywny, a nawet iluzoryczny. Analiza argumentacji postanowień oddalających skargi pokazuje niezasadne, jak uważam, podejście NSA do kryteriów stwierdzenia przewlekłości postępowania.

Argumentacja NSA sformułowana w postanowieniach oddalajacych skargi na przewlekłość postępowania, że sprawa oczekiwała (nieraz blisko dwa lata) na wyznaczenie terminu rozprawy zgodnie z kolejnością wpływu, natomiast znaczna liczba spraw wpływających ze środkami odwoławczymi do NSA stanowi przyczynę oczekiwania na wyznaczenie terminu rozprawy i co się z tym wiąże - przyczynę oczekiwania na rozpoznanie sprawy, nie znajduje uzasad-

\footnotetext{
${ }^{23}$ Zob. orzeczenia powyżej.

${ }^{24}$ Postanowienia NSA: z 16 stycznia 2015 r., I OPP 152/14: z 6 lutego 2015 r., I OPP 5/15 i z 6 lutego 2015 r., I OPP 5/15.

${ }^{25}$ Postanowienie NSA z 16 stycznia 2015 r., I OPP 152/14.

${ }^{26}$ Postanowienie NSA z 6 lutego 2015 r., I OPP 5/15.

${ }^{27}$ Postanowienie NSA z 7 grudnia 2016 r., II OPP 22/16.
} 
nienia ani w kontekście treści podmiotowego prawa do rozpoznania sprawy bez nieuzasadnionej zwłoki, ani w wyraźnych podstawach materialnych zawartych w ustawie o skardze na przewlekłość.

Zgodnie z art. 6 ust. 1 EKPC postępowanie sądowe powinno być przeprowadzone w „rozsądnym terminie”, a przy ocenie spełnienia tego warunku rozpoznania ETPC bada cztery kryteria: 1) charakter i stopień skomplikowania sprawy, 2) zachowanie skarżącego (czy przyczynił się do przedłużania postępowania), 3) zachowanie organów sądowych i administracyjnych odpowiedzialnych za prowadzenie sprawy, 4) znaczenie sprawy dla skarżacego ${ }^{28}$. Ustawa o skardze na przewlekłość zawiera własne kryteria stwierdzenia przewlekłości. Artykuł 2 ust. 2 stanowi, że „dla stwierdzenia, czy w sprawie doszło do przewlekłości postępowania, należy w szczególności ocenić terminowość i prawidłowość czynności podjętych przez sąd w celu wydania rozstrzygnięcia kończącego postępowanie w sprawie [...]. Dokonując tej oceny, uwzględnia się łączny dotychczasowy czas postępowania od jego wszczęcia do chwili rozpoznania skargi, niezależnie od tego, na jakim etapie skarga została wniesiona, a także charakter sprawy, stopień faktycznej i prawnej jej zawiłości, znaczenie dla strony, która wniosła skargę, rozstrzygniętych w niej zagadnień oraz zachowanie się stron, a w szczególności strony, która zarzuciła przewlekłość postępowania”.

Przesłanką stwierdzenia naruszenia prawa do rozpoznania sprawy bez nieuzasadnionej zwłoki jest sytuacja, w której „postępowanie zmierzające do wydania rozstrzygnięcia kończącego postępowanie w sprawie trwa dłużej niż to konieczne dla wyjaśnienia istotnych okoliczności faktycznych i prawnych" (art. 2 ust. 1 u.s.p.). Wydaje się, że w analizowanych w niniejszym artykule sprawach NSA nietrafnie oceniał spełnienie tej przesłanki. W żadnej z analizowanych spraw NSA nie odwoływał się do trudności w wyjaśnieniu stanu faktycznego sprawy czy też subsumcji okoliczności faktycznych i relewantnych norm prawnych, za przyczynę długotrwałości postępowania uznając oczekiwanie sprawy na rozpoznanie zgodnie z kolejnością wpływu i dużą liczbę spraw wnoszonych do sądu.

Należy wskazać, iż w praktyce - co potwierdzają informacje zawarte w uzasadnieniach postanowień NSA oddalających skargi na przewlekłość - przez okres kilkunastu miesięcy od dnia wpływu skargi kasacyjnej do NSA do dnia posiedzenia i rozstrzygnięcia sprawy nie sa podejmowane w danej sprawie zwykle żadne czynności mające na celu jej merytoryczne rozpoznanie, prócz jej zarejestrowania, wyznaczenia składu orzekajacego i terminu posiedzenia. Jest to poniekąd związane z charakterystyką postępowania przed NSA, który jest „sądem prawa” i który w ramach podstaw kasacyjnych ujętych w skardze kasacyjnej kontroluje zgodność z prawem orzeczenia wojewódzkiego sądu administracyjnego (art. $183 \S 1$ ustawy z 30 sierpnia 2002 r. - Prawo o postę-

${ }_{28}$ Vitkauska, Dikov (2012): 78 i n. oraz przywołane tam orzecznictwo ETPC; Hofmański, Wróbel (2010): 378 i cyt. tam orzecznictwo ETPC oraz piśmiennictwo; Nowicki (2013): 604 n. i cyt. tam orzecznictwo ETPC. 
powaniu przed sądami administracyjnymi ${ }^{29}$ ), nie przeprowadzajac zasadniczo postępowania dowodowego (art. $106 \S 3$ p.p.s.a.), a to z kolei konsumuje z kolei większość czasu w postępowaniu cywilnym lub karnym. Większość spraw jest przy tym rozstrzygana na jednym posiedzeniu sądu, przez co ten kilkunastomiesięczny czas mija właśnie na oczekiwaniu na wyznaczenie terminu posiedzenia, na którym sprawa zostaje rozstrzygnięta. Innymi słowy, kilkunastomiesięczny okres na wyznaczenie terminu posiedzenia nie jest „konieczny dla wyjaśnienia istotnych okoliczności faktycznych i prawnych”, a tym samym postępowanie takie powinno zostać uznane za przewlekłe.

Należy w tym kontekście wskazać, że w świetle treści prawa do rozpoznania sprawy w rozsądnym terminie nie jest usprawiedliwiony argument często podnoszony w uzasadnieniach postanowień NSA oddalajaccych skargi na przewlekłość, iż sprawa oczekuje na wyznaczenie terminu rozprawy zgodnie z kolejnością wpływu, natomiast znaczna liczba spraw wpływających ze środkami odwoławczymi do NSA stanowi przyczynę oczekiwania na wyznaczenie terminu rozprawy i co się z tym wiąże - przyczynę oczekiwania na rozpoznanie sprawy. Nie można bowiem odmawiać uznania postępowania ze przewlekłe, powołując się na nieodpowiednie (nieefektywne) zorganizowanie systemu sądownictwa, które stwarza warunki do systemowej przewlekłości postępowania. Jakkolwiek kwestia przyczyn długotrwałości postępowań sądowych przed NSA zasługuje na osobne, pogłębione opracowanie naukowe, to w ograniczonych ramach niniejszego artykułu uzasadniona wydaje się teza, że owa systemowa długotrwałość postępowania wynika z niedostosowania obsady orzeczniczej i personelu pomocniczego NSA do liczby rozpoznawanych spraw. Jest przy tym rezultatem zarówno przyjętego przez ustrojodawcę i ustawodawcę modelu dwuinstancyjnego sądownictwa administracyjnego, dopuszczajacego wnoszenie do NSA środków zaskarżenia od niemalże każdego orzeczenia jednego z 16 wojewódzkich sądów administracyjnych, jak i ustalenia niewystarczającej liczby etatów sędziowskich w NSA przez Prezydenta RP i braku wystarczajacych korekt w tej kwestii przez kilkanaście lat funkcjonowania zreformowanego sądownictwa administracyjnego ${ }^{30}$.

29 Dz. U. 2019, poz. 2325 ze zm. (dalej jako: p.p.s.a.)

${ }^{30}$ Do 7 lipca 2020 r. obowiązywał art. 33 P.u.s.a., który stanowił, że „Prezydent Rzeczypospolitej Polskiej, na wniosek Zgromadzenia Ogólnego Sędziów Naczelnego Sądu Administracyjnego, ustala, w drodze rozporządzenia, liczbę stanowisk sędziowskich w Naczelnym Sądzie Administracyjnym, w tym liczbę wiceprezesów tego Sądu", uchylony przez art. 4 pkt 6 ustawy z 20 grudnia 2019 r. o zmianie ustawy - Prawo o ustroju sądów powszechnych, ustawy o Sądzie Najwyższym oraz niektórych innych ustaw (Dz. U. 2020, poz. 190). Przez blisko 16 lat obowiązywania tego przepisu Prezydent RP wydał rozporządzenie z 18 lutego 2004 r. w sprawie ustalenia liczby stanowisk sędziowskich w Naczelnym Sądzie Administracyjnym oraz liczby wiceprezesów (Dz. U. 2004, Nr 26, poz. 228) oraz siedem rozporządzeń je zmieniających. Liczba etatów rosła od 50 do 127. Aktualną podstawą ustalenia liczby etatów sędziowskich w NSA jest art. 43 P.u.s.a., zgodnie z którym „Prezydent Rzeczypospolitej Polskiej, po zasięgnięciu opinii Kolegium Naczelnego Sądu Administracyjnego, określi, w drodze rozporządzenia, regulamin Naczelnego Sądu Administracyjnego, w którym ustali liczbę stanowisk sędziowskich w Naczelnym Sądzie Administracyjnym nie mniejszą niż 120, w tym liczbę wiceprezesów tego Sądu oraz liczbę sędziów w poszczególnych izbach, wewnętrzną organizację Naczelnego Sądu Administracyjnego oraz zasady wewnętrznego postępowania, biorąc pod uwagę konieczność zapewnienia sprawnego funkcjonowania Naczelnego 
W orzecznictwie ETPC na gruncie art. 6 EKPC nie jest akceptowany argument uzasadniajacy przewlekłość postępowania sądowego problemami finansowymi i organizacyjnymi systemu wymiaru sprawiedliwości. Obowiązkiem państw stron EKPC jest takie zorganizowanie systemu sądownictwa, niezależnie od kosztów, aby funkcjonowało ono w sposób zgodny z wymaganiami prawa do rzetelnego procesu sądowego, a zatem m.in. wymogiem rozpoznania sprawy w rozsądnym terminie ${ }^{31}$. A zatem to „państwo jest odpowiedzialne [...] za zwiększanie środków celem zlikwidowania zaległości w terminowym rozpoznawaniu spraw i strukturalnych wad systemu, które powodują przewlekłość postępowania" "32. Chroniczne przeciążenie sądów nie może stanowić usprawiedliwienia nadmiernie długiego czasu trwania postępowania ${ }^{33}$. W sytuacji gdy stan przewlekłości przeciąga się, stając się kwestią o charakterze strukturalno-organizacyjnym, państwo musi zapewnić podjęcie skutecznych działań w tej sferze ${ }^{34}$. Fakt, że takie zatory stały się stałym elementem postępowań, nie uzasadnia nadmiernej długości czasu ich trwania ${ }^{35}$.

Podsumowujac, nie jest usprawiedliwiona odmowa stwierdzenia przewlekłości postępowania trwającego kilkanaście miesięcy (przy braku podejmowania czynności merytorycznych $\mathrm{w}$ sprawie) $\mathrm{z}$ powołaniem się na strukturalny i systemowy charakter długotrwałego oczekiwania w NSA na rozpoznanie sprawy. Uznawanie przez NSA za uzasadnione jedynie mniej niż 1,5\% skarg na przewlekłość i przedstawiona w orzeczeniach tego sądu argumentacja prowadzą do wniosku, że skarga ta nie może zostać uznana za skuteczny krajowy środek odwoławczy, o którym mowa w art. 13 EKPC. Nie zapewnia bowiem adekwatnej ochrony naruszonego prawa do rozpoznania sprawy w rozsądnym terminie. W konsekwencji należy postulować zmianę podejścia składów orzeczniczych NSA rozpatrujących skargi na przewlekłość postępowania przed tym sądem i uwzględnienie przywołanych wyżej argumentów i orzecznictwa ETPC.

Drugim mankamentem funkcjonowania skargi na przewlekłość postępowania przed NSA jest jej rozpatrywanie przez ten sam sąd, w którym toczy się postępowanie, którego przewlekłości dotyczy skarga. Zgodnie bowiem z art. 4 ust. 3 u.s.p., ,jeżeli skarga dotyczy przewlekłości postępowania przed wojewódz-

Sądu Administracyjnego, jego izb i organów, specyfikę postępowań prowadzonych przed Naczelnym Sądem oraz liczbę i rodzaj rozpoznawanych spraw". W rozporządzeniu Prezydenta RP z 4 lipca 2020 r. - Regulamin Naczelnego Sądu Administracyjnego (Dz. U. 2020, poz. 1202) liczbę etatów w NSA ustalono na 127 (§ 2 ust. 1).

${ }^{31}$ Tak np. wyroki Wielkiej Izby ETPC: z 16 września 1996 r. w sprawie Süßmann przeciwko Niemcom, skarga nr 20024/92, oraz z 18 lipca 1999 r. w sprawie Bottazzi przeciwko Wtochom, skarga nr 34884/97.

${ }^{32}$ Hofmański, Wróbel (2010): 384.

${ }^{33}$ Wyroki ETPC: z 1 lipca 1997 r. w sprawie Probstmeier przeciwko Niemcom, skarga nr 20950/92; z 24 maja 1991 r. w sprawie Vocaturo przeciwko Wtochom, skarga nr 11891/85.

${ }^{34}$ Wyroki ETPC: z 13 lipca 1983 r. w sprawie Zimmermann i Steiner przeciwko Szwajcarii, skarga nr 8737/79 oraz z 10 lipca 1984 r. w sprawie Guincho przeciwko Portugalii, skarga nr 8990/80.

${ }^{35}$ Wyrok ETPC z 7 lipca 1989 r. w sprawie Unión Alimentaria Sanders S.A. przeciwko Hiszpanii, skarga nr 11681/85. 
kim sądem administracyjnym lub Naczelnym Sądem Administracyjnym - właściwy do jej rozpoznania jest Naczelny Sąd Administracyjny”. Powyższa regulacja rodzi problem w zakresie bezstronności obiektywnej sądu i realizacji prawa do bezstronnego sądu (art. 45 ust. 1 Konstytucji i art. 6 ust. 1 EKPC). Skoro bowiem, jak wykazano, długotrwałość postępowania przed NSA ma charakter systemowy i strukturalny, to składy orzekajace w przedmiocie skargi na przewlekłość moga nie cechować się wystarczającym stopniem obiektywizmu przy ocenie przewlekłości postępowania przed własnym sądem, a w szczególności przy orzekaniu o zadośćuczynieniu pieniężnym wypłacanym od Skarbu Państwa - Prezesa NSA. W pewnym uproszczeniu można ocenić, że istnieje ryzyko powstania wrażenia $\mathrm{w}$ odbiorze społecznym, w tym u stron postępowania, że NSA i jego sędziowie orzekają w takiej sytuacji „we własnej sprawie”.

W tym kontekście należy pamiętać, że elementem prawa do bezstronnego sądu jest tzw. bezstronność obiektywna sędziego (sądu) oznaczająca, że w odczuciu zewnętrznego (obiektywnego) obserwatora nie powinno powstawać wrażenie, że jakieś okoliczności powodują stronniczość sędziego. Kryterium obiektywne odnosi się do ustalenia, czy w danej sprawie mogło powstać obiektywne wrażenie braku bezstronności sędziego, a zatem wrażenie w odczuciu zewnętrznego (obiektywnego) obserwatora ${ }^{36}$. Istotne znaczenie w tym kontekście ma zatem wrażenie braku bezstronności ${ }^{37}$. Kluczowe jest bowiem zapewnienie zaufania, jakie sądy muszą mieć w demokratycznym społeczeństwie ${ }^{38}$. Istnieje - jak wskazał Trybunał Konstytucyjny - „interes publiczny (dobro wspólne) polegający na ukształtowaniu zewnętrznego obrazu wymiaru sprawiedliwości, tworzącego w społeczeństwie przekonanie, iż sąd jest bezstronny”. Tylko sądy złożone z bezstronnych sędziów, których postępowanie także na zewnątrz ich urzędu służy obrazowi bezstronnego wymiaru sprawiedliwości, stwarzaja, w odbiorze społecznym, gwarancje sprawiedliwego rozpatrzenia sprawy ${ }^{39}$.

Takie wrażenie braku bezstronności może wywoływać sui generis „efekt mrożący”, zniechęcający strony postępowań przed NSA do wnoszenia skarg na przewlekłość. Być może część stron obawia się skutku, jaki wniesienie skargi na przewlekłość w toku postępowania przed NSA będzie miało na kierunek rozstrzygnięcia sprawy głównej przez ten sąd i powstania stanu uprzedzenia względem strony.

Oczywiście najlepszym sposobem wyeliminowania tego rodzaju zarzutów byłoby zastapienie obecnego modelu „instancji poziomej” rozpatrującej skargi na przewlekłość modelem skargi dewolutywnej. W przypadku NSA jest to niemożliwe, z uwagi na usytuowanie tego sądu na szczycie pionu sądownictwa

${ }^{36}$ Garlicki (2008): 154. Zob. również wyrok ETPC z 15 grudnia 2005 r. w sprawie Kyprianou przeciwko Cyprowi, skarga nr 73797/01.

${ }^{37}$ Zob. wyroki ETPC: z 6 czerwca 2000 r. w sprawie Morel przeciwko Francji, skarga nr 34130/96; z 15 grudnia 2005 r. w sprawie Kyprianou przeciwko Cyprowi, skarga nr 73797/01; z 1 października 1982 r. w sprawie Piersack przeciwko Belgii, skarga nr 8692/79; z 22 października 1984 r. w sprawie Sramek przeciwko Austrii, skarga nr 8790/79.

${ }^{38}$ Wyroki ETPC: z 24 lutego 1993 r. w sprawie Fey przeciwko Austrii, skarga nr 14396/88; z 26 października 1984 r. w sprawie Cubber przeciwko Belgii, skarga nr 9186/80; z 24 maja 1989 r. w sprawie Hauschildt przeciwko Danii, skarga nr 10486/83.

${ }^{39}$ Wyrok TK z 27 stycznia 1999 r., K 1/98. 
administracyjnego i nieistnienie sądu instancyjnie wyższego. Godnym rozważenia postulatem byłoby dlatego ustawowe powierzenie tych skarg do rozpoznania Sądowi Najwyższemu i vice versa - skarg na przewlekłość postępowania przed SN do rozpoznania przez NSA. Powinno to być ograniczone do sytuacji, w których wnoszący skargę na przewlekłość kwestionuje jedynie długotrwałość postępowania przed NSA, a nie wcześniejszych etapów postępowania. Jakkolwiek w obecnym stanie prawnym pomiędzy SN i NSA nie istnieją żadne relacje orzecznicze, to wydaje się, że wprowadzenie postulowanego rozwiązania nie zaburzyłoby odrębności ustrojowej i kompetencyjnej obu sądów. Skarga na przewlekłość postępowania sądowego jest bowiem instrumentem ochrony prawa do rozpoznania sprawy bez nieuzasadnionej zwłoki i sąd ją rozpatrujący nie ingeruje w merytoryczny zakres i istotę rozpoznawanej sprawy sądowej. Stąd dla lepszej realizacji prawa do bezstronnego sądu uzasadnione jest powierzenie SN rozpoznania skargi na przewlekłość postępowania przed NSA - organowi wymiaru sprawiedliwości o równie wysokiej jak NSA pozycji ustrojowej.

\section{UWAGI PODSUMOWUJĄCE}

Przeprowadzone rozważania wykazały, że praktyka funkcjonowania skargi na przewlekłość postępowania przed NSA budzi wątpliwości, czy stanowi ona skuteczny mechanizm ochrony naruszonego prawa do rozpoznania sprawy w rozsądnym terminie (art. 6 oraz art. 13 EKPC). W latach 2015-2020 strony postępowań przed NSA wniosły jedynie 212 takich skarg, z których NSA uwzględnił tylko 3. Tak mało skarg uwzględniono, mimo że - jak wykazano w niniejszym artykule - średni czas oczekiwania na rozstrzygnięcie sprawy wynosi ok. 18-24 miesięcy od daty wpływu skargi kasacyjnej, a stale rośnie też liczba spraw oczekujacych na rozpoznanie przez ponad 24 miesiące - w 2020 r. było to już 29\% wszystkich skarg kasacyjnych. Na koniec 2020 r. blisko 300 spraw oczekiwało na rozpatrzenie ponad 3 lata. Problem długotrwałości postępowania przed NSA ma charakter systemowy i strukturalny, przy czym jest związany przede wszystkim z niewystarczająca liczbą etatów sędziowskich i urzędniczych w NSA względem wpływu spraw. Argumentacja prezentowana w ustabilizowanym orzecznictwie NSA oddalającym skargi na przewlekłość, powołująca się na oczekiwanie danej sprawy na rozpoznanie zgodnie z kolejnością wpływu spraw i dużą liczbę skarg kasacyjnych wpływających do tego sądu, nie znajduje uzasadnienia w świetle standardów wynikajacych z orzecznictwa ETPC. Prowadzi bowiem do przerzucenia na jednostkę skutków niewydolności organizacyjnej, kadrowej i finansowej sądownictwa. Z uwagi na wątpliwości dotyczące naruszenia prawa do bezstronnego sądu nieprawidłowy wydaje się także mechanizm rozpoznawania przez NSA skarg na przewlekłość postępowania przed tym sądem. De lege ferenda godna rozważenia byłaby nowelizacja art. 4 ust. 3 u.s.p. i powierzenie Sądowi Najwyższemu rozpatrywania skarg na przewlekłość postępowania przed Naczelnym Sądem Administracyjnym. 
Hofmański, P., Wróbel, A. (2010). Komentarz do art. 6 EKPC, [w:] L. Garlicki (red.), Konwencja o ochronie praw człowieka i podstawowych wolności. Tom: 1: Komentarz do artykułów 1-18. Warszawa: 241-461.

Brzozowski, W., Krzywoń, A., Wiącek, M. (2018). Prawa człowieka. Warszawa.

Celińska-Grzegorczyk, K. (2018). Odpowiedzialność odszkodowawcza za naruszenie prawa strony do rozpatrzenia sprawy bez nieuzasadnionej zwłoki w postępowaniu sądowoadministracyjnym po nowelizacji z 30 listopada 2016 r. Zeszyty Naukowe Sądownictwa Administracyjnego 2(77): 53-63.

Garlicki, L. (2008). Pojęcie i cechy „sądu” w świetle orzecznictwa Europejskiej Konwencji Praw Człowieka, [w:] A. Szmyt (red.), Trzecia władza. Sądy i Trybunały w Polsce. Gdańsk: 140-160.

Kładoczny, P., Pietryka, A., Bernatt, M., Grabowska, B. (2010). Skarga na przewlekłość postępowania. Warszawa.

Kłak, C.P. (2008). Pojęcie przewlekłości postępowania sądowego. Prokuratura i Prawo 12: 63-80.

Krakowiak, M. (2007). Charakter prawny skargi o stwierdzenie przewlekłości postępowania cywilnego. Monitor Prawniczy 15: 834-850.

Nowicki, M.A. (2013). Wokół Konw encji Europejskiej. Komentarz do Europejskiej Konwencji Praw Człowieka. Warszawa.

Pietryka, A. (2015). Przewlekłość jako problem strukturalny w Polsce - analiza wyroku Rutkowski i Inni przeciwko Polsce. Helsińska Fundacja Praw Człowieka. <https://www.hfhr.pl/wp-content/uploads/2016/02/HFPC_analizy_I_rekomendacje_92015_ost2.pdf> [dostęp: 23.11.2020].

Ryms, W. (2010). Skarga na przewlekłość postępowania przed sądami administracyjnymi. Zeszyty Naukowe Sądownictwa Administracyjnego 5/6: 374-385.

Stefanicki, R. (2016). Skarga na przewlekłość postępowania sądowego z perspektywy standardów konstytucyjnego prawa do sądu. Przegląd Sejmowy 3: 45-60.

Vitkauskas, D., Dikov, G. (2012). Ochrona prawa do rzetelnego procesu w Europejskiej Konwencji o Ochronie Praw Człowieka. Strasbourg. <https://rm.coe.int/16806f1615> [dostęp: 23.11.2020].

\section{EFFECTIVENESS OF COMPLAINTS AGAINST THE EXCESSIVE LENGTH OF PROCEED- INGS BEFORE THE SUPREME ADMINISTRATIVE COURT (IN THE LIGHT OF CASE LAW)}

Sum mary

The article analyses the practical functioning of a complaint against excessive length of proceedings before the Polish Supreme Administrative Court. The author analysed the case law of the Supreme Administrative Court in this regard in 2015-2019 as well as statistics relating to complaints and the duration of proceedings before the Court. This analysis leads to the conclusion that such complaints are an ineffective means of protecting the infringed right to be heard within a reasonable time, which is provided for in Article 6 of the European Convention on Human Rights. The problem of long-lasting proceedings before the Supreme Administrative Court is of a systemic and structural nature, and is primarily related to the insufficient number of judges and clerks at the Supreme Administrative Court. The argumentation presented in the stabilized jurisprudence of the Supreme Administrative Court - which dismisses complaints and refers both to the fact that a given case is awaiting examination in the order of the receipt of cases by the Supreme Administrative Court and to the large number of cassation complaints submitted to this court - is not justified in the light of the standards resulting from the jurisprudence of the ECtHR. This is because such arguments lead to the consequences of the organizational and financial shortcomings of the judiciary being transferred to the individual.

Keywords: complaints; excessive length of proceedings; Supreme Administrative Court 